\title{
Denotative and Connotative Meanings in Wonderfilled Advertisement of Oreo
}

\author{
Jessie Shanthana Limesa \\ English Department, Faculty of Letters, Petra Christian University \\ Surabaya, East Java, Indonesia \\ e-mail:m11413030@john.petra.ac.id
}

\begin{abstract}
This thesis mainly deals with the denotation and connotation to exposed wonderfilled concept in Oreo video advertisement "Wonderfilled". The focus of the writer's analysis is the verbal and visual expression in the video commercial as the writer uses Chandler's denotative and connotative theory in analysing the data. Those Chandlers's and Saussure's theories helped the writer analyse the use of the verbal and visual expression in the advertisement, then, figured out the concept of wonder in Oreo video commercial. The writer analyses four video advertisement of Oreo with titled "Oreo Wonderfilled ft Kacey Musgraves", "Oreo Wonderfilled ft Chiddy Bangs", "Oreo Wonderfilled - Big Bad Wolf " and "Oreo wonderfilled ft Lols Muhlenfeld". In this research the writer used descriptive qualitative approach to describe the concept of wonderfilled in the video commercial of Oreo, that wonderfilled or wonder is having two meaning. The first meaning of wonder is thinking and the second meaning of wonder is a wonderfull feeling. From the analysis, the writer found out that the video commercial of Oreo uses denotation and connotation to associate the wonderful feeling with sharing. In doing so, Oreo used a verbal expression to build the patterned story while the visual expression pictures elements of wonder within each video to evoke wonderfulness of sharing. In conclusion, the use of verbal and visual expression are aiming to make the audiences have a wonderful feeling which is associated with sharing.
\end{abstract}

Key Words: Denotation, Connotation, verbal expression, visual expression.

Language is communication between the human being, and it is essential, we usually communicate through language. We could express our feelings and ideas through language. We express our thoughts and feeling by using signs, symbols, gestures, marks and sounds. If we study about language, each word might have the different meaning if we use it in the different place. When we communicate using language, it does not only communicate about word or letter or alphabet but also communicate through signs, gestures, sounds and symbols that could help us to express our feelings or ideas. Meanwhile, language is very important to express our ideas. In this globalization era, we face the condition where we could easily find advertisements in everywhere. This advertisement help business people to express their thoughts and sell their ideas to the consumers.

Through the commercials, the business people would like to gain the trust of the consumer to consume their product. Those business people nowadays believe that advertisements are considered a big role in the marketing world. If we are talking about ads, we could easily find advertisements anywhere and anytime as soon as we start doing something. An advertisement is a tool for the marketer to persuade and influence the consumers to buy their products. When the company produce some product, they are aiming to sell their products to gain a lot of profit, but the product must fulfil the needed of the consumers to meet both parties expectations. Through the advertisement, the companies show their product quality and lure the consumers at the same time. Because of globalisation era, it is not hard to find them today, as soon as people wake up from the bed and start their day, they will find the advertisement.

The easiest advertisement examples that we could find every day are the brochure, morning newspaper, and advertising board that we easily find it on the street while we drive a car to the university, school or office. The other example is through emails, gadgets, magazines, social media, websites and much more. Conscious or unconsciously people passed over more than a hundred advertisements in a day so, sometimes people just overload with it. People tend to sort out 
that less attractive advertisement that passed on the way of their activities and watching the attractive one.

In analyzing the data, the writer uses some theories and related studies. Firstly, the writer use the process of signification by Chandler (2007, p.2), the basic meaning of Semiotic is 'the study of signs'. Semiotic is not only involves and refers the study of 'sign' but also stands for something else such as signs, words, images, sounds, gestures, and objects. According to Saussure (Saussure 1983,66), linguistically is not about a thing and a name, but between a concept that he called it as signified and a sound pattern that he called it as the signifier. Semiotics itself, in general, is the study of sign that is created by people and we use it in our daily life.

Secondly the writer uses denotation and connotation by Chandler (2007), denotation and connotation are usually used to describe the relationship between signifier and signified. The meaning always includes the denotation and connotation. "... Denotation and connotation operate at the level of signified" (Chandler, 2007, p.137). Denotation refers to the literal meaning of a sign or words, something observable. Meanwhile, connotation refers to things that are considered as personal depending on an individual's point of view; it also can refer to the meaning behind an image interpreted by people. The connotation usually associated with person socio-cultural, so not all people have the same interpretation from one and another. This is why the writer thinks that denotation and connotation can help her in analysing the Oreo's videos advertisement.

Denotation refers to something obvious, a common-sense meaning or a literal meaning of a sign or words. In a picture, if we analyse it with denotation meaning it is referred to something that is visible to eyes or something that is observable. Meanwhile, connotation means that sign or word may be interpreted differently by different people. Connotation relies on individual interpretation if we observe a picture in a connotative way it is referred to the meaning behind the picture that interpreted by individual people or different people.

The writer also uses some studies which have been done before to get information related to the study. The thesis entitled The Denotative and Connotative Meanings in The Axe Advertisements" (Muttaqien, 2011) helps the writer to have a better understanding of how to deal denotative and connotative. Moreover, the second information that the writer uses in the research is entitled Meaning in the Process of Signification by the Advertisement of HONDA" (Wibowo, 2015)

This study used descriptive qualitative approach to get and analyze the data. In order to get the data, the writer would analyze the verbal and non verbal data from Oreo video advertisements. The writer chose four video advertisements, those four video advertisement are wonderfilledrelationship, wonderfilled-high school students, wonderfilled-big bad wolf, vampire and great white sharks and wonderfilled-welcoming the royal babies.

Since this research was intended to find out how verbal and visual expression created in the advertisement of Wonderfilled by Oreo, therefore finding the verbal and visual expression in the advertisement comes first before the writer can explain the creation of meaning through the denotative and connotative meaning. The writer picked those four videos out of eight videos advertisement of Oreo because those selected videos can be connotated to something and those videos are meaningful from the visual and verbal expression point of view. After finding out the verbal and visual expression in the advertisement, the writer would come back to answer the research question in the conclusion part. Before the writer goes deeper into the analysis for each page, below is provided with a summary of the analysis of the meaning of each heading for both advertisements. In analysing the video, the writer found similar use of verbal expression within the Oreo video. The similarities are mainly about the theme of the video "Wonderfilled" which indicated the element of wonder in context, what will happen next after the speaker give an Oreo. The plot of the video is making the audience dare to wonder. Wonderfilled in the advertisement of Oreo shows two meaning of wonder; the first wonder means that wonder as thinking and the second wonderfilled is wonderful. Oreo use this two wonder in their videos to shows the audience the meaning of wonder and wonderful. Oreo would like to emphasize that the first wonder to the audience as the mindset of thinking about something will happen in a good way to the audience after they are having or consuming Oreo. The second wonder shows that Oreo brings a wonderful feeling for the audience, they would like to shot the uniqueness of Oreo itself with the secret recipe 
of black cookie and creme filling inside the Oreo is wonderful. However the closing of the story always ends up to the audiences, the speaker would like to give an Oreo to the audience and ask the audience what would happen if they gave the audience an Oreo and emphasized on the "Wonderfilled" or the theme of Oreo. Denotative meaning in the verbal expression is identified through understanding each utterance as denotative level plays in the level of obvious and literal meaning (Chandler, 2007, p.138). However, connotative meaning requires deeper understanding such as paying attention to the association of certain idea or cultural practices according to the context within the commercial as the connotative meaning be hidden in the connotative level of signification (Chandler, 2007, p. 139).

The unit of analysis in this study was per utterance and every 5 clips from one video. Utterance means speech that was bounded by silence. One utterance analyzed in denotative and connotative meaning. The writer classified the utterances and the clips base on the first utterance and the first 5 video clips in the first second when the video starts.

\section{FINDINGS AND DISCUSSION}

Firstly, the writer would answer the first research question;

1. What is meaning of Oreo's advertisement created through verbal expressions?

2. What is meaning of Oreo's advertisement supported by visual expressions?

Table 1: The analysis of visual expression in Oreo Wonderfilled video advertisement

\begin{tabular}{|c|c|c|c|}
\hline Clip & Visual expression & Denotative & Connotative \\
\hline $\begin{array}{c}1.1 \\
(1.00- \\
1.07)\end{array}$ & wonder if I & $\begin{array}{l}\text { Blue } \\
\text { White - black } \\
\text { - oreo }\end{array}$ & $\begin{array}{l}\text { - } \begin{array}{l}\text { Blue associated with } \\
\text { confidence, trust, loyalty and } \\
\text { calmness }\end{array} \\
\text { - White symbolises purity, } \\
\text { faith and cleanliness it } \\
\text { represents a successful } \\
\text { beginning, Black associated } \\
\text { with elegance and } \\
\text { prestigious } \\
\text { - Oreo help people to unify a } \\
\text { relationship } \\
\text { - Oreo help people to connect } \\
\text { to one and another } \\
\text { - Oreo is suitable for both, } \\
\text { single and couple } \\
\text { The girl loves the guy and } \\
\text { she still imagining him }\end{array}$ \\
\hline $\begin{array}{c}2.1 \\
(3.51- \\
3.56)\end{array}$ & $\begin{array}{l}\text { IFI GAVE } \\
\text { PEOPLE } \\
\text { HOCH }\end{array}$ & $\begin{array}{l}\text { Black-white- } \\
\text { oreo }\end{array}$ & $\begin{array}{l}\text { - Oreo is suitable for } \\
\text { teenagers } \\
\text { Blue is a masculine colour; } \\
\text { according to studies, it is } \\
\text { highly accepted among } \\
\text { males. } \\
\text { - Everyone can consume oreo } \\
\text { (black/white and boy or girl) } \\
\text { does not matter } \\
\text { - Pencil and the book explain } \\
\text { that oreo is for educated } \\
\text { people } \\
\text { Oreo tell us not to keep oreo } \\
\text { by ourselves, we should }\end{array}$ \\
\hline
\end{tabular}




\begin{tabular}{|c|c|c|c|}
\hline & $160 \mathrm{TO}$ & & $\begin{array}{l}\text { share Oreo to the other } \\
\text { people (our friends for } \\
\text { example) }\end{array}$ \\
\hline $\begin{array}{c}3.4 \\
(6.21- \\
6.32)\end{array}$ & & $\begin{array}{l}\text { Wolf (several } \\
\text { large } \\
\text { carnivorous } \\
\text { mammals, } \\
\text { chains of the } \\
\text { dogs that are } \\
\text { usually } \\
\text { hunting in } \\
\text { packs) in this } \\
\text { video story, } \\
\text { Oreo using } \\
\text { the story of } \\
\text { three little } \\
\text { pigs and a big } \\
\text { bad wolf } \\
\text { which will eat } \\
\text { the pigs } \\
\text { Vampire } \\
\text { (bloodsucking } \\
\text { corpse which } \\
\text { afraid of sun } \\
\text { or light and } \\
\text { mirrors and } \\
\text { eat living } \\
\text { things such as } \\
\text { human or } \\
\text { animal) } \\
\text { Red-blood } \\
\text { Blue } \\
\text { Pink } \\
\text { Purple } \\
\text { Black }\end{array}$ & 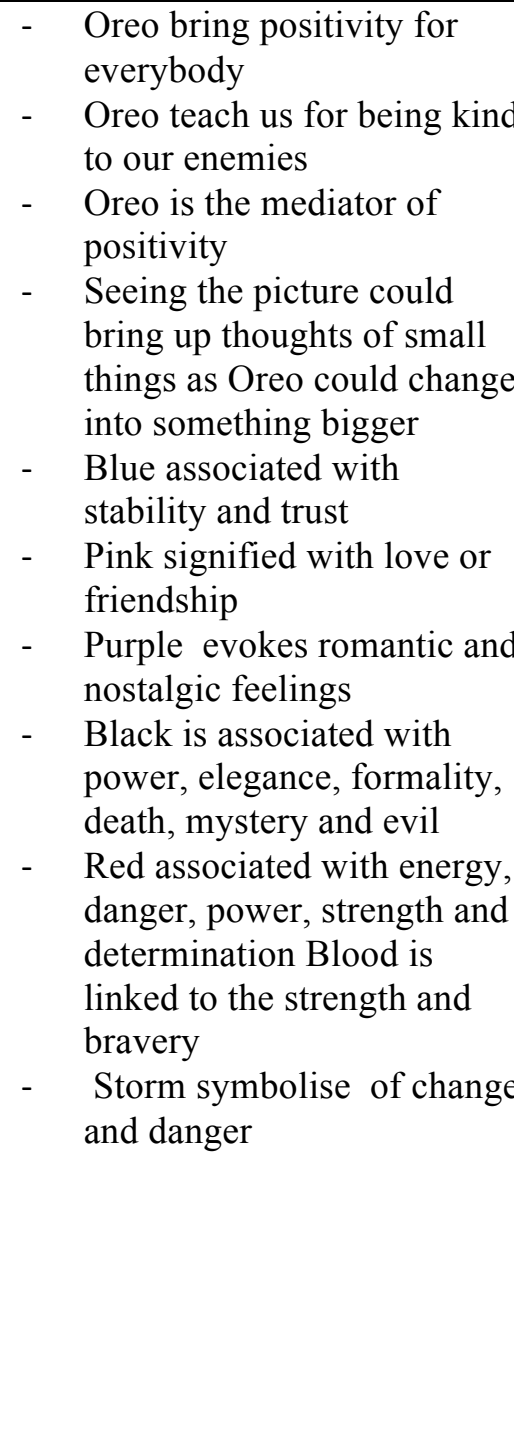 \\
\hline $\begin{array}{c}4.7 \\
(7.53- \\
8.04)\end{array}$ & $\begin{array}{l}\text { EODAY } \\
\text { EACH ONE } \\
\text { iN THER WAY i }\end{array}$ & $\begin{array}{l}\text { Light Blue } \\
\text { Pink } \\
\text { Yellow } \\
\text { White } \\
\text { Footprints } \\
\text { Baby toys } \\
\text { Crown }\end{array}$ & $\begin{array}{l}\text { - Light blue: associated with } \\
\text { health, healing, tranquillity, } \\
\text { understanding, and softness. } \\
\text { - Blue is a masculine colour; } \\
\text { according to studies, it is } \\
\text { highly accepted among } \\
\text { males. } \\
\text { - Pink: signifies romance, } \\
\text { love, and friendship. It } \\
\text { denotes feminine qualities } \\
\text { and passiveness. } \\
\text { Yellow: yellow is attention, } \\
\text { Yellow produces a warming } \\
\text { effect, arouses cheerfulness, } \\
\text { stimulates mental activity, } \\
\text { and generates muscle }\end{array}$ \\
\hline
\end{tabular}




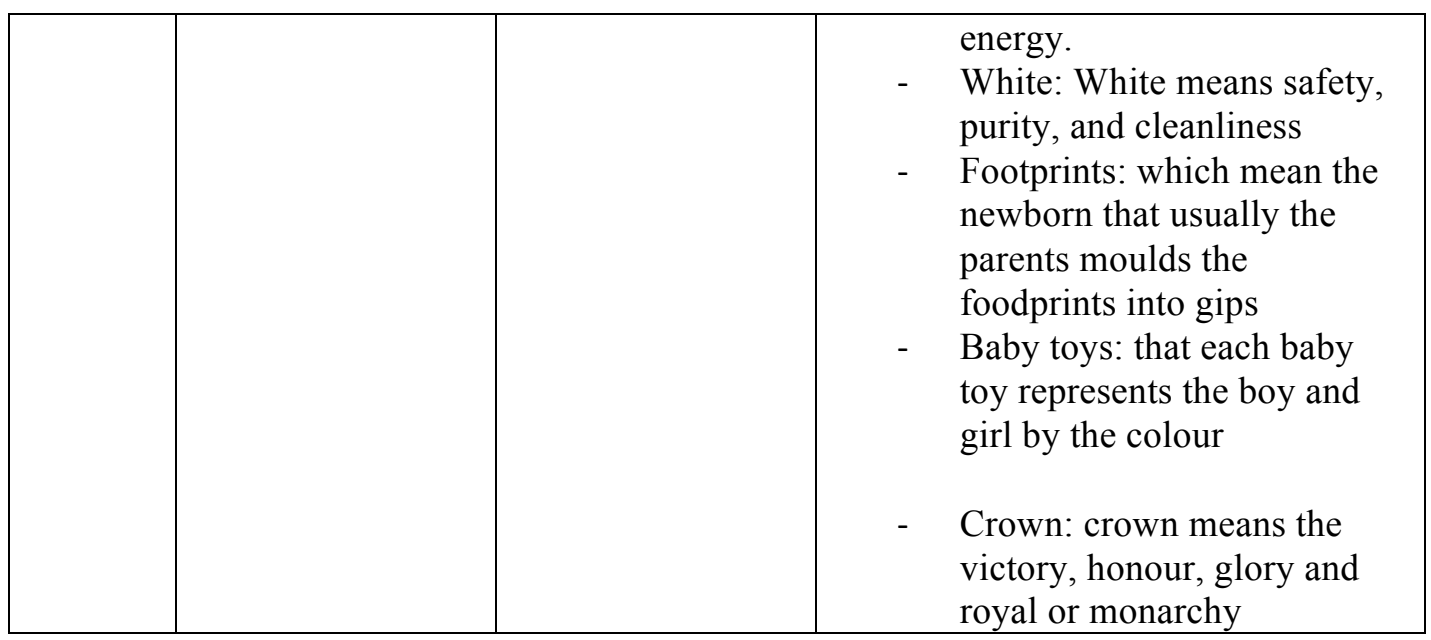

From the table above the writer think that the plot is created by daily activities that happen in the society. Some people are dreaming of having lovers or someone that could be the one who we depend on in the future. In the story of the video commercial it is also connotatively understood that the oreo is unifying the relationship between both sides (the female and male character) Besides that, the Oreo is helping them to stay connected as it pictures that shows the distance between the woman and man, even though the woman like the man but the man has already had a girlfriend.

the visual expression pretty much acts as a support in illustrating the picture and bonds between verbal and visual through picture or colour. The visual expression recorded in table 4.7 above is connotatively illustrating the bonds between illustrations. The picture of high school student that has an Oreo as their head that mean like they have been possessed by Oreo with the wonderful feeling inside them. Not only limited to that, but the visual expression in the second clip also connotatively supports the main theme and story of the oreo's plot.

The background situation where the big bad wolf that a bad character in the folk story became a good one that helps the three little pigs to arrange a party and spent time together. The vampire that is usually sucking a blood change into a different kind of the evil one.

The visual expression in the last clip is connotatively illustrating the background situation surrounding the main character. The background situation here is where the colour and the symbol could explain better than the verbal expression. The colour of blue and pink, for example, they would like to show that that colour shows the masculinity and femininity.

Although there are similarities between the first, second and the third clip such as it engage the audience to wonder, the first clip focus on the single and couple audience in the way of more visual expression on the clip. The second clip focuses more on the verbal expression in creating the elements of wonder for high school or educated people. The third clip is more focus on the visual expression in a way about our enemy. The last clip is emphasizing that Oreo is for everyone by using more the visual expression by showing the colour in the background of the video.

Table 2: The analysis of verbal expression in Oreo Wonderfilled video advertisement

\begin{tabular}{|c|c|c|c|}
\hline Video & Utterance in the video & Denotative & Connotative \\
\hline 1.1 & $\begin{array}{l}\text { Wonder if I, gave an } \\
\text { Oreo, to this cute guy that } \\
\text { I used to know. }\end{array}$ & $\begin{array}{l}\text { According to } \\
\text { dictionary.com } \\
\text { "Wonder": to } \\
\text { think or } \\
\text { speculate } \\
\text { curiously } \\
\text { The speaker } \\
\text { imagining about }\end{array}$ & $\begin{array}{l}\text { - Oreo help to } \\
\text { establish new } \\
\text { relationship (in } \\
\text { this context the } \\
\text { speaker and the } \\
\text { addressee have } \\
\text { known each } \\
\text { other) } \\
\text { Oreo remind }\end{array}$ \\
\hline
\end{tabular}




\begin{tabular}{|c|c|c|c|}
\hline & & $\begin{array}{l}\text { giving an Oreo } \\
\text { cookie to the } \\
\text { guy (that } \\
\text { considered cute } \\
\text { by the speaker) } \\
\text { that the speaker } \\
\text { already know } \\
\text { who the guy } \\
\text { referred to }\end{array}$ & $\begin{array}{l}\text { the audience to } \\
\text { wonder about } \\
\text { the person that } \\
\text { we love } \\
\text { - Something } \\
\text { wonderful is } \\
\text { going to } \\
\text { happen with } \\
\text { Oreo } \\
\text { Oreo } \\
\text { strengthen the } \\
\text { relationship }\end{array}$ \\
\hline 2.2 & $\begin{array}{l}\text { Wonder if I gave an Oreo } \\
\text { to, all the people at the } \\
\text { high school I go to. }\end{array}$ & $\begin{array}{l}\text { The speaker } \\
\text { imagining about } \\
\text { giving an Oreo } \\
\text { cookie to all of } \\
\text { the people in } \\
\text { the speaker's } \\
\text { high school go } \\
\text { to }\end{array}$ & 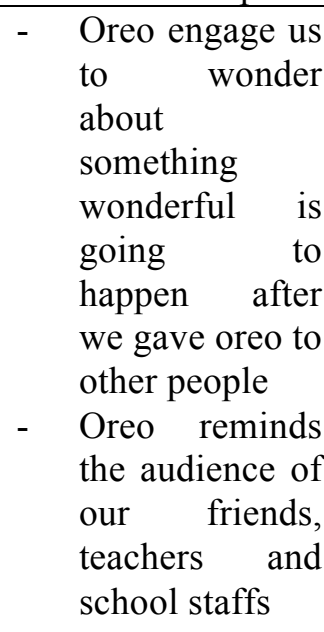 \\
\hline 3.4 & $\begin{array}{l}\text { Wonder if I gave an Oreo } \\
\text { to a vampire in a creepy } \\
\text { show, would he not act so } \\
\text { undead? }\end{array}$ & $\begin{array}{l}\text { The speaker } \\
\text { imagining about } \\
\text { giving an Oreo } \\
\text { cookie to a } \\
\text { vampire who } \\
\text { appeared in the } \\
\text { creepy show } \\
\text { (vampire is a } \\
\text { corpse who is } \\
\text { sucking blood } \\
\text { of the living) }\end{array}$ & $\begin{array}{l}\text { - } \begin{array}{l}\text { Oreo engage us } \\
\text { (the viewers) to }\end{array} \\
\text { give Oreo } \\
\text { cookie to our } \\
\text { enemies }\end{array}$ \\
\hline 4.1 & $\begin{array}{l}\text { Wonder if we took this } \\
\text { moment to celebrate all } \\
\text { of the babies, who came } \\
\text { into the world today } \\
\text { each one royal in their } \\
\text { way }\end{array}$ & $\begin{array}{l}\text { The speaker says that } \\
\text { every people have the } \\
\text { same rights of } \\
\text { celebrating the } \\
\text { newborn. }\end{array}$ & $\begin{array}{l}\text { - In society, boy } \\
\text { and girls do not } \\
\text { have the same } \\
\text { level. So Oreo } \\
\text { would like to } \\
\text { show that boy } \\
\text { or girl have the } \\
\text { same level } \\
\text { - Everybody is } \\
\text { special } \\
\text { - Oreo is for } \\
\text { everyone }\end{array}$ \\
\hline
\end{tabular}


From the table above it could be comprehended that the wonder in the first clip intended to be used at the denotative level as the meaning wonder as think.In this advertisement, oreo would like to show that a small things ad an Oreo cookie could unify relationship between two people. In this context, Oreo shows that they would unify the girl and the boy (they have been knowing each other), and the girl considered the guy that she like is cute. Oreo here, as the mediator of establishing a relationship and shows that Oreo is for both single and couple. Oreo also wants to remember the audience to the someone that the audience like or love and it also strengthens the relationship by spread kindness to everyone. The characteristic of the utterance is also understood connotatively through the context of the video. The pictures in the video make audiences understand vividly about the story that Oreo made.

However, as the theme suggests elements of wonder within the commercial, the plot creates a twist within the wonderfilled which makes the wonderfilled advertisement can also interpret as wonderful. The Oreo video commercial "Wonderfilled" associates wonder as think about something else with wonderful things. For that purpose, the video commercial urges the audiences to wonder something else that unexpectedly hilarious as the result of the wonder about something wonderful where Oreo aim to.

Wonder in the second clip is intended to play the denotative meaning from the table above. In this second video it describes the place of the video, they showed in high school. By uttering the wonder here, the speaker would like to show that he is a high school student or in other words, he is well-educated people. To show the element of wonder in the advertisement, they dare the audience to think in their first lyric. From this utterance in the second video shows that Oreo is addressed to the educated people that they interpreted as high school students. However, the speaker would like to remind the audience of the past time and not to forget about the teacher, school staff and our friend in the moment of wondering. The last connotation is Oreo consumed by educated people, the measurement of educated people here is high school student.

Third wonder is intended on the denotative meaning. The speaker said that he would like to give an Oreo to the Vampire in a crepy show. That is not what it means in this utterance; the vampire described as the enemy of the people. Vampire is believed as a corpse from the Eastern European folklore, which sucks the blood of living people. In the third wonder, it does mean that interpreted wonder as think about the things which will happen after we passed an Oreo to somebody else.

Fourth wonder is intended on the denotative meaning. The speaker said that he would like to take this moment to celebrate about the newborn whoever it is. This utterance means that everyone is special, the babies described as people. Babies are the newborn that is just birth from the womb of a mother; people are born from the womb of a mother. Therefore, babies here is connotated as the people because every people is come from the womb and have a childhood. The By using this situation, Oreo would like to show to the world that boy and girl are equal. Oreo also would like to show that everybody is special and Oreo is for everyone whoever you are.

Nevertheless, all of the four wonders are shown about the differences target market. Although the video illustrated with four difference clips and story, Oreo would like to show that their product is suitable for everyone from the single and couple, the educated people, the enemies and the babies which interpreted as everyone. However, those videos are showed about the wonderful things inside and the joy of wonder that Oreo dare to the audience. In this commercial, the verbal expression acts as the medium of the intended meaning

\section{CONCLUSION AND SUGGESTIONS}

In analysing the data, the writer comprehends that the four commercials have, However, as the theme "Wonderfilled" suggests elements of wonder within the video commercials, the wonder feeling is ambiguous and could be easily misinterpreted. Thus, the misinterpretation of the wonder creates an unexpectedly hilarious situation that urges folk story from the audiences. The first clip plays on the connotative domain as the wish is intended to show its connotative meaning but get misinterpreted which causes an unexpected situation where the speaker will wonder about the cute guy that she loves. 
And the second video is connotated about the high school student or educated people that would like to share an oreo with other people. Telling about teenager life in school, in denotative meaning, the speaker would like to give oreo to everybody in his school. Connotatively it told us as the audience that Oreo is suitable for teenagers and addressed to the well-educated people. The third video is talking about the enemy in our life and we should change them with our kindness by giving amall cookies as in Oreo cookies. The last video is talking about the boy, girl, and level of people in the society but all of the stuill could enjpoy Oreo.

The success in making the audiences give attention to the commercial is the utterances said about wonder something good going to happen and after that, the speaker would like to give it to the audience to continue the story.In conclusion, Oreo would like to engage all of the audience with differences background such as the single and couple, enemy and friends and also all people in all kind of level to enjoy Oreo together by sharing.

customers who are in the same-age group and customers who are in different-age (older) group.

Also, the writer hoped that the readers would conduct a further research related to this research. Those who are interested in analyzing the similar topic to this study could give another limitation to the customer's background; for example by choosing the customers based on their profession. Moreover, it would be much better if other researchers do an interview with the insurance agents regarding their thought and consideration while using persuasive strategies.

\section{REFERENCES}

Bain, Z. (2015, February 20). Moreover, The World's Best Selling Cookie is... Retrieved September 24, 2017, fromhttp://www.delish.com/food/news/a41508/oreos-world-top-selling-cookie. Chandler, D. (2007). Semiotics The Basics (2nd ed). London: Routledge.

Clements, S. (2013, March 31). How Kraft Food Made Oreo a Global Brand. Retrieved September 20, 2017, from http://www.businesstoday.in/magazine/lbs-case-study/how-kraft-foods-won-overcustomers-in-china-and-india/story/193162.html

Diaz, A.C. (2013, May 14). Can Oreo's new 'Wonderfilled' Campaign sap the cynicism out of your day?. Retrieved September 18, 2017, from http://adage.com/article/behind-the-work/oreo-swonderfilled-campaign-sap-cynicism-day/241459/

Elliott, S. (2013, May 10). Creating an Ad Campaign for Oreos, as They Turn 101. Retrieved October 12, 2017, from ttp://www.nytimes.com/2013/05/11/business/media/creating-an-adcampaign-for-oreos-as-they-turn-101.html

Gunaxin. (2016, December 4). Five Sweet cookie Brand Empire. Retrieved September 20, 2017, from https://grub.gunaxin.com/five-cookie-brand-empires/171219

Longman Dictionary of Contemporary English (3rd ed). (2001). Edinburgh Gate, Harlow.

Muttaqien, Z. (2011). The Denotative and Connotative Meanings in The Axe Advertisements.

Unpublished Thesis of Sarjana S1. Yogyakarta: Universitas Islam Indonesia.

Nof, R. (2013, February 4). Real-Time Advertising Has Arrived, Thanks To Oreo and The Super

Bowl. Retrieved September 20, 2017, from

https://www.forbes.com/sites/roberthof/2013/02/04/real-time-advertising-has-arrived-thanks-tooreos-and-the-super-bowl/

Sack, D. (2014, October 23). The Story of Oreo: How an Old cookie become a modern Marketing Personality. Retrieved September 22, 2017, from https://www.fastcompany.com/3037068/thestory-of-oreo-how-an-old-cookie-became-a-modern-marketing-personality Spector, D. (2012, March 6). Oreo: How The Best-Selling Cookie In the World Is Made. Retrieved September 26, 2017, from http://www.businessinsider.com/oreo-how-the-best-selling-cookie-inthe-world-is-made-2012-3/? IR=T

Thielman, S. (2013, July 31). Ad of the Day: Is Chiddy Bang's Oreo 'Wonderfilled' Song the Best yet ?. Retrieved September 21, 2017, from http://www.adweek.com/brand-marketing/ad-day-oreogets-edge-chiddy-bangs-version-wonderfilled-151561/ 
Watercutter, A. (2013, April 2). How Oreo Won The Marketing Super Bowl With A Timely Blackout Ad On Twitter. Retrieved September 26, 2017, from

https://www.wired.com/2013/02/oreo-twitter-super-bowl/

Wibowo, N. (2015). Meaning in the Process of Signification by the Advertisement of HONDA. (TA No. 02012125/ING/2015). Unpublished undergraduate thesis, Petra Christian University, Surabaya

Wiechmann, J. G. (1996). NTC's Dictionary of Advertising (2nd ed). Lincolnwood, Illinois, NTC Publising Group.

Fera, A.R. (2013, May 14). Behind Oreo's Unusual, “Wonderfilled” New Spot. Retrieved September 20, 2017, from https://www.fastcompany.com/1682953/behind-oreos-unusualwonderfilled-new-spot. 